City University of New York (CUNY) CUNY Academic Works

\title{
We Need a Loud and Fractious Poor
}

Jeff Maskovsky

CUNY Graduate Center

Frances Fox Piven

cUNY Graduate Center

\section{How does access to this work benefit you? Let us know!}

More information about this work at: https://academicworks.cuny.edu/gc_pubs/656

Discover additional works at: https://academicworks.cuny.edu

This work is made publicly available by the City University of New York (CUNY).

Contact: AcademicWorks@cuny.edu 


\title{
We Need a Loud and Fractious Poor
}

\author{
Jeff Maskovsky \\ Graduate Center and Queens College, City University of New York, New York, NY, USA; \\ jeff.maskovsky@qc.cuny.edu
}

\section{Frances Fox Piven}

Graduate Center, City University of New York, New York, NY, USA;

fpiven@hotmail.com

\begin{abstract}
This article explores the political consequences of four decades of consistent humiliation of the poor by the most authoritative voices in the land, and offers insights into ways that new movements are creating spaces for poor people's political voices to surface and become relevant again. Our specific concern is the challenge that the current humiliation regime poses to those who seek to revive radical, disruptive and fractious anti-poverty activism and politics. By humiliation regime, we mean a form of political violence that maltreats those classified popularly and politically as "the poor" by treating them as undeserving of citizenship, rights, public goods or resources, and, importantly, that seeks to delegitimate them as political actors. Our article demonstrates the historical importance of authoritative voices in inspiring political unrest involving poor and working people, charts the depoliticising effects of poverty politics and governance since the 1980s, and highlights the new political possibilities that are surfacing now not just to defeat the very dangerous political forms of Trumpism and the new white nationalism but that seek as well to create something that looks like justice, freedom and equality. We insist on the importance of loud and fractious poor people's politics and call on scholars to direct attention to the incipient political potentialities of poor people today.
\end{abstract}

Keywords: poverty, protest movements, United States, politicisation, inequality, humiliation

\section{Introduction}

Many readers will agree that we are in a new movement era in the United States. Perhaps it began with Occupy, an unlikely set of sleep-ins in public spaces by smallish groups of young people that, unlikely or not, captured the nation's attention and brought "We are the 99 percent" into the lexicon of popular politics. It was certainly extended by the Black Lives Matter movement and the local and national activist work by Black liberation organisations that protested police corruption, demanded criminal justice reform and used social media to bring national attention to racial inequality and racialised state violence. And the \#MeToo movement, also using savvy new media tactics, has reframed the national conversation about sexual violence. Suddenly, widening inequality, racial inequality and sexual predation surfaced in new ways as political issues. Related events, from the occupation of the Wisconsin state capitol, to the spreading teacher strikes, to the rise of Bernie Sanders and Alexandra Ocasio Cortez, to the call to abolish ICE, all bear the imprimatur of these movements. 
Still, what strikes us about the ensuing widespread (and to our minds welcome) turmoil is that the voices of the poorest Americans who bear the heaviest burden as wealth and income drift to the top can scarcely be heard, at least not as "the poor". To be sure, Reverend Barber and Liz Theoharis have announced a new "Poor People's Campaign" but this has not yet garnered widespread political or popular support. ${ }^{1}$ Meanwhile, the Trump administration's most recent budget proposals ensure the acceleration of the trend of worsening poverty amidst flagrantly displayed wealth by proposing huge new spending cuts to safety net programs, and this in the wake of a new round of large tax cuts that benefit the rich (Committee for a Responsible Federal Budget 2019). History suggests that the apparent silence of the poor amidst the ongoing tumult of American politics - the women's marches, teacher strikes, and Democratic Party insurgencies, for example-is ominous. After all, the major policies that established the American welfare state, including our social security, affordable housing, healthcare and income support programs, were all inaugurated during periods when the poor asserted themselves and their demands, by marching, demonstrating, refusing to pay rent and resisting evictions, taking over government offices, and rioting in the streets (Piven and Cloward 2012).

So why the current quiescence among the worst off? We suspect that it reflects the dispiriting effects of over four decades of consistent humiliation of the poor by the most authoritative voices in the land, especially by elected political leaders. We see this quiescence as related very closely to three additional political developments: political polarisation borne from the failures and limitations of centrist politics; the rise of authoritarian politics; and the weakening of political energies of poor people's organisations, especially labour, civil rights and women's rights organisations that have lost ground in recent decades as elites extended their political assault beyond the poor to different fractions of the US middle classes.

In this paper we seek to develop this thematic with specific concern for the challenge that the current humiliation regime poses to those who seek to revive radical, disruptive and fractious anti-poverty activism and politics. By humiliation regime, we mean a form of politics that maltreats those classified popularly and politically as "the poor" by treating them as undeserving of citizenship, rights, public goods or resources, and, importantly, that seeks to delegitimate them as political actors (Baldwin and Crane 2020; De Genova and Roy 2020; Sheppard et al. 2020). Scholars have devoted significant attention to the politics of humiliation as part of a broader inquiry into the politics of passion and emotion in various contexts (Ahmed 2015; Marcus 2000, 2002), and critical poverty scholars have documented extensively the indignities, cruelties, and mortifications to which the poor have been subjected in the United States (see, for example, Goode and Maskovsky 2001; Lawson and Elwood 2018; Piven and Cloward 1993; Soss et al. 2011). Our contribution is to trace how the politics of humiliation have shaped poverty politics in the last 30 years, with a specific emphasis on their depoliticising effects, and to highlight as well the extent to which new movement activities work to unsettle the humiliation regime that has been in place in the United States at least since the 1980s (Crane et al. 2020). 
Our article develops in three parts. First, we demonstrate the historical importance of authoritative voices in inspiring political unrest involving poor and working people. Here we explain also what we mean by poor people's movements, with a specific eye towards their relevance today. Second, we chart the depoliticising effects of poverty politics and governance since the 1980s. Our point here is to show how the consensus politics of the Democratic Party, and some Republicans, combined with the moral opprobrium from the Right to displace militant poverty politics and to discourage mobilisations involving poor people. This also opened the door for the resurgence of white nationalism in the form of Trumpism, which poses particular political challenges to poor people. Third, we identify several promising trends, borne in the new movement era, that may help to repoliticise poverty at the level of popular politics. Central here, we argue, are the new political possibilities that are surfacing now in opposition to the very dangerous political forms of Trumpism and the new white nationalism. We are interested in exploring new forms of political thought and action that contest both white nationalist right-wing populism and the politics of Democratic centrism in the pursuit of something that looks like justice, freedom and equality. Our question is the extent to which these new forms are creating spaces for poor people's political voices to surface and become relevant again in broader politics. We conclude with a brief discussion of the importance of loud and fractious poor people's politics.

\section{The Power of Authority}

Let us begin by considering the large role that Franklin Delano Roosevelt's rhetorical appeals to the American people played in giving confidence to the Depression-era poor, and courage also to workers who were beginning to fight for the right to unionise. Roosevelt campaigned for the Presidency in 1932 promising to "build from the bottom up and not from the top down ...", to put "faith once more in the forgotten man at the bottom of the economic pyramid" (Roosevelt 1938:159-206, 625). And while FDR's early measures about the right to organise were in fact toothless, they nevertheless proclaimed the right, signalling a degree of political openness to labour. And the proclamations in turn allowed John L. Lewis, the leader of the mine-workers union, to send organisers into the coalfields proclaiming "the President wants you to organize!" One organiser reported back that he had organised nine locals on Tuesday (Bernstein 1971:114).

Even more obvious, Democratic presidents in the 1960s, worried about the impact of enlarging numbers of newly urbanised black urban voters on presidential contests, began to endorse the demands of the largely southern black freedom movement. This encouragement did not quash the movement as some commentators on the interplay of movements and electoral politics argued (cf. Piven and Cloward 2012). Rather, it encouraged and emboldened the movement, thus helping to produce the monumental victories that finally eroded the America system of racial apartheid.

The political fallout of responding to the actual demands of the Black freedom movement was likely, however, to be costly for a Democratic administration 
reliant on the then Democratic South. The initial strategy was to try to avoid demands for dismantling the Jim Crow system in the South by reaching out directly to newly urbanised Blacks with a variety of social programs named after what everyone could agree were the social problems of the inner city, including youth crime, mental health, neighbourhood blight, and poverty. Consider the words of Lyndon Baines Johnson in his 1964 State of the Union message:

This administration today, here and now, declares unconditional war on poverty in America. I urge this Congress and all Americans to join with me in that effort. It will not be a short or easy struggle, no single weapon or strategy will suffice, but we shall not rest until that war is won. The richest nation on earth can afford to win it. We cannot afford to lose it. 1,000 dollars invested in salvaging an unemployable youth today can return $\$ 40,000$ or more in his lifetime. Poverty is a national problem, requiring improved national organization and support. But this attack, to be effective, must also be organized at the State and the local level and must be supported and directed by State and local efforts. For the war against poverty will not be won here in Washington. It must be won in the field, in every private home, in every public office, from the courthouse to the White House. The program I shall propose will emphasize this cooperative approach to help that one-fifth of all American families with incomes too small to even meet their basic needs. (Johnson 1964)

As a consequence of the several federal initiatives that preceded and followed Johnson's statement, not only did poverty levels in the United States fall substantially, but the Black freedom movement followed the federal lead and embraced the cause of the poor (Marable 2007).

We need to comment on this last development. Movements that label themselves poor are rare in the United States, for the simple reason that to be called poor is not a proud appellation in our Protestant and market-oriented culture. To the contrary, poverty remains a mark of personal failure and God's disfavour. This sore spot itself discourages the poor from protest. Further, the rise of business political influence in the past several decades has been accompanied by a deluge of propaganda that fastens onto the sore spot and aggravates it, thus contributing to the disgrace that produces the quiescence of the poor.

That business has been on a political roll, gaining influence in both political parties, establishing a formidable and unprecedented lobbying presence in Washington DC and in the state capitols, and dominating the mass media with Fox News.

It seems reasonable to date the political rise of big business to the famous Powell memo, a confidential document from 1971 directed to the US Chamber of Commerce and calling on business leaders to become politically active and assert themselves in US politics. The basic agenda was the roll back of the policies that had been created mainly in the 1930s and 1960s. In other words, the Powell memo was a manifesto calling for a business mobilisation against the US welfare state. It was not hard to devise the business arguments for why this was necessary. Indeed, the basic argument was merely an update of age-old arguments about the dangers of government interference with the "natural law" of laissezfaire. In the contemporary period, the argument ran, globalisation raised new dangers. Globalisation means greater capital mobility and accelerated trade, 
intensifying worldwide competition in a kind of global race to the bottom. Workers in the United States are in effect in competition with workers everywhere, forcing "wage flexibility", which of course means lower earnings and precarious terms of employment, for all working people. Similarly, competition for investment capital leads governments to lower tax levels and roll back business regulations in the effort to attract investors, thus stripping the public sector of the resources on which a welfare state depends, and also inevitably enlarging the economic share of the 1\% (Sheppard et al. 2020). ${ }^{2}$ In the popular variant of this argument, globalisation is treated as an exogenous development, imposed on helpless governments and helpless publics alike. But the path to the economic changes encompassed by globalisation is paved by the trade deals and financial deregulation that governments craft with the intention of making globalisation possible. In other words, globalisation itself is a political development, and therefore strongly influenced by an energised business politics (Piven 2001).

\section{The Problem of Poverty Politics}

What of mainstream poverty politics? From the 1970s to 1996, the year welfare "reform" passed, poverty was associated with the concept of "dependency". Dependency came to refer, famously, to the condition of poor women who maintain their families with neither a male breadwinner nor an adequate wage and rely for economic support on a stingy and politically unpopular government program called Aid to Families with Dependent Children (AFDC). Before that, in the New Deal era, most Americans distinguished between welfare and non-welfare forms of public provision and saw only the former as creating dependents. For example, work conditioned benefits like pensions or sick days were taint-free but AFDC was not. In this scenario, independence was associated with industrial wage labour while a kind of dependence was associated with reliance on AFDC. Importantly, as Fraser and Gordon (1994) emphasise, New Deal welfare dependency was a form of good dependency-keeping women at home raising kids, even in the absence of a wage-earning spouse, thus helping to stabilise white workingclass families and the Fordist industrial social order itself. And in this arrangement, exclusion from this kind of good dependency was the true marker of deviance and pathology in the American political imaginary. ${ }^{3}$

After the New Deal Coalition broke up in the 1960s, dependency began to take on a more sinister meaning in US politics, and this correlated with the emergence and expansion of the humiliation regime that we see as having played such an important role in depoliticising poverty. During the Reagan era, the attack on the "welfare queen" - a key prop of the humiliation regime - was crucial to New Right anti-big government policy advances, which included the rise of supply side economics and other neoliberal ideological tropes, the breaking of the Fordist social compact, the rollback of the social wage, the rise of non-unionised post-industrialism and the acceleration of globalisation (Piven 2001; Schram 2000). This was also the era when "the urban underclass" concept gained traction in academic circles among both the liberal-left and the right (Di Leonardo 2000; Goode and Maskovsky 2001). 
In the Clinton era, the Democratic Party policy elite responded to the steady drumbeat of anti-dependency rhetoric coming from the right by adjusting their rhetoric to espouse a vision of prosperity freighted with invocations of individualism, personal responsibility, and reinvented (smaller) government. Clinton Democrats even claimed that welfare reform would actually permit the elevation of the poor by prodding them to throw off the yolk of "bad" dependency and rapidly attaching them to low-wage post-industrial work.

The ideological assault against "bad" dependency widened considerably in the 2000 s, especially after $9 / 11$. With welfare reform in the rear-view mirror, new fractions of the middle classes (especially lower-middle class white suburbanites) came under fire and financial duress and the libertarian attack against government, any government, gained traction. In this period, the basis for popular compassion and political support for the poor all but vanished, except among a small group of anti-poverty activists and their supporters.

Here it is useful to tell the story of the rise of anti-government sentiments because they played an outsized role in the construction of the humiliation regime, and in the reworking of the notions of dependency and independence in the national popular imagination to which it was linked. During the early and mid-2000s, the liberal strategy of offering narrow, technocratic policy reforms targeted to the "working poor" fell largely on deaf ears. The liberal establishment attempted to make the "working poor" the new deserving poor, independent enough from government to justify and legitimate some forms of government support and protection. The program known as the Earned Income Tax Benefit, which subsidises the earnings of the working poor (and of the low wage businesses that employ them), reflects this stance. Yet conservatives remained relentless in their attacks on welfarism and dependency. Emboldened by the War on Terror and the Iraq War, the Bush administration froze domestic spending and injected new forms of moral reckoning into social welfare provisions. They were unafraid to impose economic suffering on those they defined as lacking in virtue and morality, especially at a time of national sacrifice in support of two wars. Moreover, it was clear they would get few votes from low-income people in any case. Indeed, Republicans, and many Democrats, were highly invested in shrinking budgets regardless of the social cost and in re-directing national politics away from welfare state expansion. To be sure, there were some new approaches bruited about. These included faith-based initiatives and marriage promotion as solutions to poverty, as well as themes that emphasised workforce attachment, social support and other ideas that came from the mainstream liberal policy establishment. But these instruments were not connected, as liberals who advocated for them had hoped, to substantial pools of public funding.

For its part, and this is crucial for understanding the consolidation of the current-day humiliation regime, the mainstream liberal political and policy establishment seriously overestimated the political benefits of its technocratic prowess. In fact, in an utter failure of technocracy, it assumed repeatedly, against all kinds of evidence to the contrary, that its own "objective" social scientific and policy expertise could overcome the crude domestic politics unleashed by conservatives. By putting their faith repeatedly in behavioural science, social scientific objectivity, 
technological innovation, and beyond-the-political-fray rationality, the liberal establishment engaged ironically in what can only be described as a kind of magical thinking - an irrational and non-reality tested belief that the technocratic behaviourism they perfected would prevail somehow, without a political fight, over the political passions stoked by conservatives. For confirmation of this, simply look at the policy influence (or lack thereof) of narrowly construed books that attempted to explain carefully, in the most rational of terms, why poor men could not be good fathers or why poor mothers did not marry the fathers of their children. ${ }^{4}$ At best, this work inspired or legitimated anaemic anti-poverty efforts such as the Obama Administration's underfunded-and racist-My Brother's Keeper program. At worst, it served as confirmation of right-wing perspectives about the depravities and moral failings of the undeserving poor.

These developments were compounded by the rise of austerity politics and the activation of the populist (not conservative) right, in response to the Obama Administration's attempts at economic stimulus in the aftermath of the global economic collapse of 2008. The rise of the anti-tax, anti-government Tea Party played a crucial role. Funded into existence by extractive and finance capital, it was extremely effective in naming and then popularising opposition to "government dependency" as part of its effort to constrain the Obama administration's attempt to devise a social democratic response to economic crisis. The Tea Party turned out to be an unwieldy and unpredictable political formation (about which we will say more shortly). For now, let us emphasise that if the rise of conservatism highlighted the "workforce attachment at any cost" welfare policy imperatives of the Clinton era, replacing cash assistance with moral opprobrium as the primary basis for intervention, the austerity politics that followed read the poor out entirely from questions about the health and welfare of the body politic (Maskovsky 2001). And in the context of austerity politics, dependency worked in new ways as a political category and the humiliation regime broadened to encompass new groups who were formerly popularly and politically considered to be "deserving". In some respects, groups formerly associated with profligacy and individualised dependency were left alone in the fight over austerity. "Welfare queens", already vanquished in the 1990s, were ignored in the 2012 presidential campaign cycle. But in 2012 teachers and pensioned government employees became the targets: "government dependent" profligates living life too large off the government dime. Ultimately the attack on "government dependency" spread so wide as to encompass "the 47 percent of the US population" whom Romney condemned for not paying federal income tax but taking government services anyway. (To arrive at $47 \%$, one has to ignore contributions to social security and payroll taxes; once these are included the number of non-tax paying Americans goes down to 15\%.) Katherine Cramer's (2016) book, The Politics of Resentment, shows how Wisconsin Republicans linked resentment of these sorts to those against the "liberal elite" while Jane Collins (2017) shows how resistance to these tactics helped pave the way for a national effort to unsettle the humiliation regime and rethink the economy along more just lines of argument, about which we will say more below. 
As the humiliation regime broadened to encompass more people, we see the reconfiguration of social citizenship so that the question became who is expected to make sacrifices in the name of national belt tightening and security, not who is entitled to a living wage or welfare supports or even who has the "proper moral comportment" to be deserving of limited support. Dependence on government, in this formulation, is a full-fledged threat to a nation fully engaged in a war on terror and contending with an economic collapse. When the humiliation of such a broad swath of people becomes the operative logic guiding popular and political deliberation over wealth redistribution and social order it creates a new political calculus that so erodes social and economic citizenship that citizenship becomes almost entirely sacrificial, as Wendy Brown (2016) so brilliantly puts it. Citizens are those whose very existence is increasingly predicated upon sacrifices so taxing that they can be depleted, politically, socially, and economically, by their allegiance to the nation. Importantly, this understanding also has the additional consequence of reading those who are in need out of the circle of citizenship (De Genova and Roy 2020).

Third came the rise of Trumpism. If the Tea Party was nominally a movement of libertarian, anti-tax, deficit scolds, its rank and file turned out to be more concerned about race and immigration than it was about debt and fiscal constraint. And this rank and file is Trump's base. The intellectual, popular and policy imperatives of Trumpism are rooted in white nationalism, not libertarianism or conservatism. White nationalism is to a certain extent the deviant spawn of the liberal forms of white ethnic identity politics that emerged in the 1970s and 1980s, in the aftermath of the Black power movement of the 1960s. It has festered on the fringe of the Republican Party since the 1970s, encouraged by the kind of cynical crypto race-baiting that has been a hallmark of Republican politics since the 1960s, when, in the context of the Civil Rights movement, Republicans put concerted effort into appealing to white southerners' racial resentments in order to gain their support. Trumpism is thus notable by its overt articulation of white racial resentments that have long been exploited, sub rosa, by the Republican Party but which Trump has made explicit. That his followers are united less by a coherent set of anti-big government ideological precepts (they mostly support Social Security and Medicaid) and more by the resentment that their racial privilege has eroded, is suggestive of the limits and limitations of the post-racial colourblind politics of the conservative movement (Maskovsky 2020; Williamson et al. 2011). Indeed their anti-PC complaints represent a white nationalist assertion that eschews both the race-neutral colourblindness favoured by neoconservatives and the kind of racial categorisation or overt race talk that is typically associated with liberal multiculturalism and liberal social policies, such as affirmative action. Yet Trump is invested in a different kind of race talk. Trump's antiglobalist, anti-immigrant stance are political gestures meant to conjure for his followers the glory days of a white ethnic past (De Genova and Roy 2020). So too is his talk about Black America, in which he expresses mostly pity for the harrowing conditions of life in the inner city. He blames Democrats for decades of policy experimentation that locked Black Americans in the inner city, in an intergenerational quagmire of familial dysfunction and violence (this argument is of course 
resonant with that made by liberal scholars and policy makers [Baldwin and Crane 2020]). Yet his prescription for change, ironically, is to suggest that the Clintonera welfare-to-work regime should be extended to all other safety net programs, so people have to work, for instance, in order to get food stamps or subsidised housing or government health insurance. Of course, Trump's description of the plight of inner-city residents has very little to do with reality for most African Americans, most of whom are not poor and do not live in the urban core. But it signals something else entirely to his white middle-class supporters, who see Black Americans both as government dependents for which they hold disdain and incoherently as the preferred recipients of government largess. Thus, Trumpism reinvests the humiliation regime with the trope of the depraved Black welfare recipient. In fact, it does a great deal to bring the welfare queen back as the spectre of pathologised dependency that downwardly mobile white middle-class people are scrambling to avoid for themselves. Theirs is a politics of racial resentment nourished by grievances over the lost privileges of straight white cisgender men. And the solution for the precarious status of many white middle-class men is, for Trump, a return not to the 1980 s or 1990 s, but to the mid- $20^{\text {th }}$ century, and to the industrial economy and welfare statism of that era. This is a rather brazen expression of a desire to return to that era as it actually existed, with its systematic racist and sexist hierarchies wholly intact but without the housing programs and New Deal work projects that were the hallmarks of New Deal welfarism. Trump's support, however uncertain, of social security and Medicaid offends conservative intellectuals, while the racist and sexist parts of the equation offend almost everyone else. Yet we cannot lay the blame entirely on Trump and his followers for their sense of disenfranchisement. It is quite real and has long been a political barrel of gunpowder. The rise of Trumpism was only possible because the New Right's attempt to impose post-racial colourblind politics failed to manage America's "race relations" problem, as did liberal multiculturalism (Maskovsky 2020). And, of course, because conservative and centrist Democrat economic policies followed the neoliberal mould and produced unprecedented economic inequality (Sheppard et al. 2020).

In the 1990s, welfare reform re-formulated the historic division between the deserving and undeserving poor around the category of productivity in an effort to concentrate on the pragmatics of free market prosperity. Then the conservative ascendency reinstated moral opprobrium as the primary basis for the doling out of services and resources and for cutting domestic spending. In austerity politics, the battle was reframed in terms of the selfishness of government dependents and the unsustainable "generosity" of government itself. And then Trumpism revived older debates about dependency, welfarism, and work as both tragedy and farce. Across all of these changes we can see the extent to which longstanding political arrangements that freight access to public resources, and political recognition, by sorting out who was a legitimate social and economic citizen of the nation, have now frayed beyond recognition, with the forced humiliation of the poor as one consequence and with a mad-dash scramble to formulate workable political programs in defence of ever-ambiguous category of "the middle class" as another. Trumpism is one such attempt at a workable political program 
organised around explicitly racial-and racist-criteria. This is not to say that different visions of those who are living lives of economic precarity-as victims, threats, salt-of-the-earth survivors, or leaches on a resources-strained system-do not resurface or that new poverty management policies will not reinforce or contradict these political logics. But it is to say that the race, nationality, sexual, class, and gender politics that shaped debates over independence and dependence over the last four decades are no longer working in the same way that they once past. Needless to say, this is a dangerous and politically volatile situation.

\section{New Political Possibilities}

How might we put poverty back on the political agenda in this dangerous and volatile situation? And what forms of political action in the present can unsettle the humiliation regime that has depoliticised poverty? We began this article by mentioning a new movement era forged through the actions of Occupy Wall Street, the Movement for Black Lives, the \#MeToo movement, and, we should add, the multi-faceted resistance to the Trumpism presidency. In this final section, we explore three aspects of these insurgent politics that might contribute to the repoliticisation of poverty and to the emergence of protest movements involving low-income participants (Crane et al. 2020). We admit at the onset that many of the potentialities that we identify are nascent, unstable, and impermanent. Yet concerns for racial and economic justice, for freedom and equality, and for security and stability continue to surface routinely in the United States (Baldwin and Crane 2020), despite the humiliation to which a widening group of Americans are subjected. We are interested specifically in the kinds of political talk, organisation building, and organising efforts that open up political possibilities for poor people's movements in this uncertain context.

At the level of ideology and political talk, new insurgent movements help to unsettle decades of effort to blame and humiliate those at the bottom of the economic ladder. To start, there is no doubt that the Occupy movement was a very significant political intervention that opened up a space for addressing issues of poverty, dispossession and displacement. As a non-hierarchical mass movement focused on equality and economic fairness, Occupy provided a powerful, if seemingly fleeting, Left alternative to the Right-wing populism and austerity policies that have gripped the United States since the economic crisis of 2008. And, as we mention at the start of this paper, its rhetoric about the $1 \%$ versus the $99 \%$ was undeniably effective at reintroducing the critique of inequality into mainstream politics after a three-decade absence (for a critical analysis of his movement, see, for example, Maskovsky and Susser 2016).

The Movement for Black Lives is also in many respects a form of Black insurgent politics that unsettles the humiliation regime and that opens up a space for antipoverty protest. Like Occupy, BLM places economic justice at the centre of its political project, explicitly linking worker rights and protections, publicly funded jobs programs, progressive taxation, reparations, and other measures to its calls for criminal justice reform, the end of cash bail, unfair sentencing, and to a broader critique of antiblackness, not just the racist and discriminatory practices 
associated with one branch of government or another, but of the centrality of Black impoverishment and social and physical death to the white social order itself (Camp and Heatherton 2016; Crane et al. 2020; Maskovsky 2020; Mullings with Gordon forthcoming; Williams 2015). If the "99 percent" was a call to action against business elites and their control over the economy and state, "Black Lives Matter" must be seen as performing similar rhetorical work that condemns the humiliating, unjust treatment of people of colour in the criminal justice system, and draws connections between this treatment and the wider racist treatment of Black communities.

Even the \#MeToo and \#TimesUp movements play a role here. Although most of the attention that these movements have generated comes from the media shaming of the treatment of women by wealthy celebrities such as Harvey Weinstein and Matt Lauer, a closer look at their political priorities shows considerable attention to the ways that race, class and immigration status influence the harassment of, and violence against, women. Indeed, these movements have placed the plight of low-wage workers at the centre of their struggles, calling attention to the lack of protections and persistent harassment experienced by many women in jobs as temporary workers, secretaries, care workers, domestic workers, and in other low-wage positions.

The recent upswing in labour agitation by teachers in Chicago, Los Angeles, Oklahoma, Arizona, and in other locations also brings other aspects of poverty into view. In this case, it is not the teachers themselves who are calling themselves poor. Rather, it is their students, their under-resourced schools without up-to-date textbooks or decent facilities, with whom striking teachers have aligned themselves. Indeed, state and local officials and politicians have had difficulty challenging the spreading teacher movement because the teachers have worked hard to include demands for improved schools along with their demands for fair pay for teachers.

These developments may lift the heavy and suffocating weight of the humiliation regime, making it possible for the poor themselves to find their voices and recover their agency. This is our hope. History argues that without the participation of the poor, without their understandings of what a modicum of social justice demands, and without the bodies of the poor in the struggle, it is unlikely that we will reverse the worst cruelties of recent American politics and policy.

\section{Endnotes}

1 https://www.poorpeoplescampaign.org

2 These developments are also frequently attributed to the rise of neoliberalism, famously understood as a set of free market economic imperatives and economising governmental logics. We prefer to emphasise the Powell memo, showing that the call for the reassertion of business class power preceded, and was indeed the founding condition for, the rise of both globalisation and neoliberalism (Harvey 2010).

3 Black urban women were excluded from welfare benefits until they were brought onto the rolls in large numbers in the mid-1960s under pressure from the welfare rights movement, as were many immigrants. Considerable scholarly attention has been given to the privatist, heteronormative, nuclear-family-oriented surburbanised cultural and political ideals associated with the independent affluent worker of the industrial era New Deal. The 
majority of white wage labourers - the quintessential affluent industrial workers of the immediate post-WWII era-were in fact dependent not only on non-welfare forms of public provisioning such as social security and unemployment insurance but on the unpaid (and paid) work of women in their households and beyond. The affluent industrial workers were also dependent on the government in other ways, through the Gl Bill, federal highway policies, and other government programs that enabled the rise of the segregated, white middle class suburbs.

4 We are thinking here, of course, about Kathryn Edin and Maria Kefalas's Promises I Can Keep (2011) and about the entire Russell Sage and University of Chicago backed fatherhood promotion research, including Marsiglio and Roy's Nurturing Dads (2012). It strikes us as significant that the liberal establishment has accepted and reinforced the gendered terms of debate as they have been handed down by generations of poverty researchers influenced by the Chicago School of Sociology with the work of Frazer and through the Culture of Poverty and Underclass formulations, from the 1960s and 1980s respectively (Goode and Maskovsky 2001).

\section{References}

Ahmed S (2015) The Cultural Politics of Emotion. New York: Routledge

Baldwin D L and Crane E S (2020) Cities, racialized poverty, and infrastructures of possibility. Antipode this issue

Bernstein I (1971) The Turbulent Years: A History of the American Worker, 1933-1941. Boston: Houghton Mifflin

Brown W (2016) Sacrificial citizenship: Neoliberalism, human capital, and austerity politics neoliberalism, human capital, and austerity politics: Wendy Brown. Constellations 23 (1):3-14

Camp J T and Heatherton C (eds) (2016) Policing the Planet: Why the Policing Crisis Led to Black Lives Matter. London: Verso

Collins J L (2017) The Politics of Value: Three Movements to Change How We Think About the Economy. Chicago: University of Chicago Press

Committee for a Responsible Federal Budget (2019) "Analysis of the President's FY 2020 Budget." 11 March https://www.crfb.org/papers/analysis-presidents-fy-2020-budget (last accessed 11 December 2019)

Cramer K J (2016) The Politics of Resentment: Rural Consciousness in Wisconsin and the Rise of Scott Walker. Chicago: University of Chicago Press

Crane A, Elwood S and Lawson V (2020) Re-politicizing poverty: Relational re-conceptualizations of impoverishment. Antipode this issue

De Genova N and Roy A (2020) Practices of illegalization. Antipode this issue

Di Leonardo M (2000) Exotics at Home: Anthropologies, Others, American Modernity. Chicago: University of Chicago Press

Edin K and Kefalas M (2011) Promises I Can Keep: Why Poor Women Put Motherhood Before Marriage. Berkeley: University of California Press

Fraser N and Linda G (1994) A genealogy of dependency: Tracing a keyword of the U.S. welfare state. Signs 19(2): 309-336.

Goode J and Maskovsky J (eds) (2001) The New Poverty Studies: The Ethnography of Power, Politics, and Impoverished People in the United States. New York: New York University Press

Harvey D (2010) A Brief History of Neoliberalism. Oxford: Oxford University Press

Lawson V and Elwood S (eds) (2018) Relational Poverty Politics: Forms, Struggles, and Possibilities. Athens: University of Georgia Press

Marable M (2007) Race, Reform, and Rebellion: The Second Reconstruction and Beyond in Black America, 1945-2006. Basingstoke: Palgrave Macmillan

Marcus G E (2000) Emotions in politics. Annual Review of Political Science 3:221-250

Marcus G E (2002) The Sentimental Citizen: Emotion in Democratic Politics. University Park: Pennsylvania State University Press 
Marsiglio W and Roy K (2012) Nurturing Dads: Social Initiatives for Contemporary Fatherhood. New York: Russell Sage Foundation

Maskovsky J (2001) Afterword: Beyond the privatist consensus. In J Goode and J Maskovsky (eds) The New Poverty Studies: The Ethnography of Power, Politics, and Impoverished People in the United States (pp 470-482). New York: New York University Press

Maskovsky J (2020) Other people's race problem: Trumpism and the collapse of the liberal racial consesns in the United States. In J Maskovsky and S Bjork-James (eds) Beyond Populism: Angry Politics and the Twilight of Neoliberalism (pp 167-181). Morgantown: West Virginia University Press

Maskovsky J and Susser I (2016) Critical anthropology for the present. In J G Carrier (ed) Anthropology in Crisis (pp 154-174). London: Berg

Mullings L with Gordon I (forthcoming) Neoliberal racism and the movement for Black lives. In J Hooker and H Nahuel (eds) When Rights Ring Hollow.

Piven F F (2001) Globalization, American politics, and welfare policy. Annals of the American Academy of Political and Social Science 577(1):26-37

Piven F F and Cloward R A (1993) Regulating the Poor: The Functions of Public Welfare. New York: Vintage

Piven F F and Cloward R A (2012) Poor People's Movements: Why They Succeed, How They Fail. New York: Random House

Roosevelt F D (1938) The Public Papers and Addresses of Franklin D. Roosevelt, Volume I (ed S I Roseman). New York: Random House

Schram S F (2000) After Welfare: The Culture of Postindustrial Social Policy. New York: New York University Press

Sheppard E, Sparks T and Leitner H (2020) World class aspirations, urban informality, and poverty politics: A North-South comparison. Antipode this issue

Soss J, Fording R C and Schram S F (2011) Disciplining the Poor: Neoliberal Paternalism and the Persistent Power of Race. Chicago: University of Chicago Press

Williams B C (2015) Introduction: \#BlackLivesMatter. Cultural Anthropology Fieldsights 29 June https://culanth.org/fieldsights/introduction-black-lives-matter (last accessed 11 December 2019)

Williamson V, Skocpol T and Coggin J (2011) The Tea Party and the re-making of Republican conservatism. Perspectives on Politics 9(1):25-43 